\title{
Composição bromatológica e fracionamento de carboidratos e proteínas de aveia-preta e triticale sob corte e pastejo ${ }^{1}$
}

\section{Fernando Silveira Ferolla ${ }^{2}$, Hernán Maldonado Vásquez ${ }^{3}$, José Fernando Coelho da Silva ${ }^{3}$, Alexandre Pio Viana ${ }^{4}$, Felipe Nogueira Domingues ${ }^{5}$, Fábio Nunes Lista ${ }^{2}$}

\author{
1 Projeto financiado pelo CNPq e pela FAPERJ. \\ 2 Programa de Pós-graduação em Produção Animal - Centro de Ciências e Tecnologias Agropecuárias (CCTA), Universidade Estadual do Norte \\ Fluminense (UENF), Av. Alberto Lamego, 2000, Campos dos Goytacazes, RJ CEP: 28015-620. \\ 3 LZNA/CCTA/UENF. Bolsista de produtividade em Pesquisa (CNPq). \\ ${ }^{4}$ Laboratório de Melhoramento Genético Vegetal (LMGV), CCTA/UENF. \\ ${ }^{5}$ Laboratório de Zootecnia e Nutrição Animal (LZNA) Centro de Ciências e Tecnologias Agropecuárias (CCTA), Universidade Estadual do \\ Norte Fluminense (UENF), Av. Alberto Lamego, 2000, Campos dos Goytacazes, RJ CEP: 28015-620.
}

RESUMO - Avaliaram-se a composição bromatológica e as frações de carboidratos e proteínas de aveia-preta ( Avena strigosa Schreb) cv. EMBRAPA 29 e triticale (X triticosecale Wittmack) cv. IAC 3 semeados em abril, maio e junho e colhidos nos sistemas corte e pastejo a intervalos de 30 dias nas condições do norte do estado do Rio de Janeiro. O experimento constou de um fatorial $2 \times 2 \times 3$, arranjado em blocos ao acaso, com três repetições, composto dos fatores: gramínea, sistema e época de plantio. Os teores de matéria seca (MS) diferiram entre espécies e sistemas e foi superior no triticale e no sistema pastejo, porém, não diferiram dentro de cada espécie nas diferentes épocas de plantio. Houve efeito significativo dos fatores e/ou de suas interações sobre os teores de fibra em detergente neutro (FDN), FDN livre de cinzas e proteína (FDNcp) e lignina; o teor de FDN foi maior no triticale semeado em abril. Os teores médios de carboidratos totais (\% CT na MS) não diferiram entre as espécies e os sistemas, porém, foram maiores em abril, exceto para o triticale no sistema de pastejo; o teor médio geral foi de 77,83\% da MS. Do total de carboidratos na MS, 25,5\% no triticale e 19,20\% na aveia-preta foram compostos de carboidratos não-fibrosos (CNF). A fração B2 variou apenas entre as épocas, de 45,32 a $49,13 \%$, respectivamente, para as épocas de plantio em abril e junho no triticale sob o sistema de corte. A fração das proteínas solúveis em detergente neutro (fração $\mathrm{A}+\mathrm{B} 1+\mathrm{B} 2$ ) diferiu apenas entre os teores médios de carboidratos totais (\% CT na MS). Considerando o valor médio de PB obtido e sua disponibilidade no triticale e na aveia-preta, pode-se indicar essas forrageiras como excelentes fontes de proteína.

Palavras-chave: carboidratos fibrosos, cinzas, composição química, fibra em detergente neutro, forrageira de inverno, proteína bruta

\section{Chemical composition and carbohydrate and protein fractionation of black- oat and triticale under harvest or grazing}

\footnotetext{
ABSTRACT - Black-oat (Avena strigosa Schreb.) cv. EMBRAPA 29 and Triticale (X triticosecale Wittmack) cv. IAC 3 were studied under harvest or grazing every $30 \mathrm{~d}$, in three planting seasons (April, May and June), in order to evaluate the bromatological composition under Northern Rio de Janeiro State conditions. The experiment was done in a factorial arrangement $2 \times 2 \times 3$, in randomized block design with three replicates, being the factors: grass, systems and planting season. The dry matter (DM) concentration differed between species and cutting systems, with Triticale showing higher DM under grazing; however there were no differences within species in relation to planting seasons. Significant effects were found between factors and/or its interactions on the levels of neutral detergent fiber (NDF), NDF free of ash and crude protein (NDFacp) and lignin, with higher NDF for Triticale planted in April. Total carbohydrate concentration (\% TCHO in DM) did not vary among species and cutting systems, however slightly higher concentrations were found on April, except for Triticale under grazing system; average \% TCHO was $77.83 \%$ in DM. From this total (\% TCHO in DM), 25.5 and $19.20 \%$ in the Triticale and in Black-oat, respectively, were composed by non fiber carbohydrate (\%NFC in TC). The B2 fraction (\%B2 in TC) varied only among planting periods in Triticale under harvest system, ranging from 45.32 to $49.13 \%$, respectively, for April and June. The protein fractionation showed high protein solubility in forage DM, but statistical differences were found only among planting periods for the soluble protein fractions in neutral detergent (fractions $A+B 1+B 2$ ). Considering the average $C P$ value obtained and its availability it is possible to point out these forages as excellent protein sources.
}

Key Words: ash, black-oat, chemical composition, crude protein, fiber carbohydrate, neutral detergent fiber

Este artigo foi recebido em 15/12/2005 e aprovado em 17/8/2007.

Correspondências devem ser enviadas para fferolla@uenf.br. 


\section{Introdução}

As forrageiras de inverno constituem uma alternativa para suplementação de volumoso por se tratarem de forragem de boa qualidade com significativa produção de MS (Alvim, 1989). Faria \& Corsi (1995) indicaram essas culturas nas condições do Brasil Central, onde a época de plantio recomendada é em março-abril, visando ao crescimento das plantas nos meses de temperaturas mais baixas. Esses autores obtiveram produções de 3 a 5 toneladas de MS por hectare com cortes a cada 30-35 dias, o que representa produções inferiores às de plantas de clima tropical, porém de alto valor nutritivo.

Gomes \& Stumpf (2001) avaliaram a produção de MS (kg/ha) e os teores de PB e FDN da aveia-preta cv. EMBRAPA 29 sob o efeito de três intervalos de corte (21, 35 e 49 dias) e três níveis de nitrogênio $(65,130$ e $260 \mathrm{~kg} / \mathrm{ha}$ de $\mathrm{N})$. Os teores de $\mathrm{PB}$ variaram inversamente com os intervalos de corte $(20,5 ; 18,8$ e $18,0 \%)$ e positivamente com os níveis de nitrogênio $(17,4 ; 19,1$ e 20,9\% PB).

Reis et al. (2002) realizaram estudos com triticale e observaram teores de PB, FDN, FDA e lignina de 19,7; 42,3; 24,8 e $3,4 \%$ para o primeiro corte, respectivamente. No material obtido no segundo corte, houve diminuição do teor de PB e aumento nos teores de FDN, FDA e lignina. Segundo os autores, o florescimento destas plantas é responsável por estes resultados em virtude da maior porcentagem de caule na massa obtida no segundo corte.

A constituição de compostos nitrogenados e carboidratos oscila durante o ciclo vital da planta, pois a parede das células vegetais cresce para proporcionar estabilidade estrutural e conferir proteção aos órgãos reprodutores e às sementes. Com base no fracionamento de carboidratos e compostos nitrogenados pelo Sistema Cornell (Cornell Net Carbohydrate and Protein System - CNCPS) e no modo diferenciado de como os microrganismos do rúmen utilizam esses compostos, procura-se a sincronia entre a disponibilidade de energia e nitrogênio na tentativa de reduzir as perdas de compostos nitrogenados e a produção de metano, o que permite estimar o escape ruminal de nutrientes (Sniffen et al., 1992).

Este trabalho foi realizado com o objetivo de avaliar a composição bromatológica e o fracionamento dos compostos nitrogenados e de carboidratos da aveia-preta e do triticale sob os sistemas corte e pastejo, semeados em três épocas de plantio (abril, maio e junho).

\section{Material e Métodos}

O experimento de campo foi realizado em Campos dos Goytacazes, nas dependências do Setor de Forragicultura do Centro de Ciências e Tecnologias Agropecuárias (CCTA), da Universidade Estadual do Norte Fluminense, Campus Darcy Ribeiro (UENF), localizado a $21^{\circ}, 44^{\prime}, 47^{\prime \prime}$ de latitude sul e $41^{\circ}, 18^{\prime}, 24^{\prime \prime}$ longitude oeste e a 12 m de altitude. O clima, segundo a classificação de Köppen, é descrito como Aw quente e úmido, com verão chuvoso, temperatura média de $24^{\circ} \mathrm{C}$ e precipitação pluviométrica de $1.023 \mathrm{~mm}$. O solo, classificado como Latossolo Amarelo Distrófico, classe textural franco-argilo-arenosa, com 54\% de areia, $7 \%$ desilte e $39 \%$ de argila, apresentou as seguintes características:

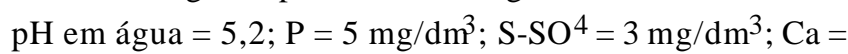
$17,5 \mathrm{mmol} / \mathrm{dm}^{3} ; \mathrm{Mg}=8,3 \mathrm{mmol} / \mathrm{dm}^{3} ; \mathrm{K}=1,8 \mathrm{mmol}_{\mathrm{c}} / \mathrm{dm}^{3}$; $\mathrm{Al}=1,0 \mathrm{mmol}_{\mathrm{c}} / \mathrm{dm}^{3} ; \mathrm{H}+\mathrm{Al}=27,7 \mathrm{mmol}_{\mathrm{c}} / \mathrm{dm}^{3} ; \mathrm{MO}=26,0 \mathrm{~g} / \mathrm{dm}^{3}$; $\mathrm{CTC}=55,8 \mathrm{mmol}_{\mathrm{c}} / \mathrm{dm}^{3} ; \mathrm{V} \%=50 \% ;$ Sat $\mathrm{Al}=3 \%$; $\mathrm{Fe}=39,8 \mathrm{mg} / \mathrm{dm}^{3} ; \mathrm{Cu}=0,4 \mathrm{mg} / \mathrm{dm}^{3}, \mathrm{Zn}=2,1 \mathrm{mg} / \mathrm{dm}^{3} ;$ $\mathrm{Mn}=6,2 \mathrm{mg} / \mathrm{dm}^{3}$ e B $=0,24 \mathrm{mg} / \mathrm{dm}^{3}$.

A correção do solo foi realizada com aplicação de calcário dolomítico ( 2 t/ha) e a adubação de plantio, com superfosfato simples $(500 \mathrm{~kg} / \mathrm{ha})$ aplicado junto às sementes. Após 20 dias de plantio, realizou-se aplicação de nitrogênio (20 kg/ha, na forma de uréia) e $\mathrm{K}_{2} \mathrm{O}$ (10 kg/ha, na forma de $\mathrm{KCl}$ ). Depois de cada corte/pastejo foram realizadas aplicações de nitrogênio ( $90 \mathrm{~kg} / \mathrm{ha}$, na forma de uréia) e $\mathrm{K}_{2} \mathrm{O}$ (30 kg/ha, na forma de $\mathrm{KCl}$ ).

O experimento constou de um fatorial $2 \times 2 \times 3$, arranjado em blocos ao acaso, com três repetições, composto dos fatores: espécie, sistema e época de plantio. As duas espécies avaliadas foram aveia-preta (Avena strigosa Schreb) cv. EMBRAPA 29 e triticale (X triticosecale Wittmack) cv. IAC 3, semeadas em três épocas de plantio, abril (21/4/2004), maio (20/5/2004) e junho (21/6/2004), e os dois sistemas de colheita foram corte e pastejo. Ambos os cultivares (aveia-preta cv. EMBRAPA 29 (Garoa) e triticale cv. IAC 3) foram semeados em densidade de $100 \mathrm{~kg}$ de sementes por hectare em todos os tratamentos.

As parcelas de corte mediam $5 \times 5 \mathrm{~m}$ e os cortes foram realizados a $10 \mathrm{~cm}$ do solo, deixando-se $1 \mathrm{~m}$ de bordadura. Tomou-se o peso da porção a ser avaliada e retiraram-se amostras para determinação da composição bromatológica. As parcelas de pastejo mediam $10 \times 10 \mathrm{~m}$, de modo que, antes de cada pastejo, foram coletadas amostras de $1 \mathrm{~m}^{2}$ para retirada de alíquotas representativas para análise bromatológica.

No sistema de pastejo, utilizou-se em cada parcela um bovino com $300 \mathrm{~kg}$ de peso corporal, mantido em pastejo durante a noite ( 8 às $6 \mathrm{~h}$ do dia seguinte), visando preservar um resíduo de $20 \mathrm{~cm}$. Na época de abril, os cortes/pastejos foram realizados aos 60 dias pós-plantio (dpp) e, a partir da época maio, foram realizados aos $45 \mathrm{dpp}$, uma vez que foi identificada alta emissão de inflorescências nas avaliações realizadas em abril. 
As análises químicas do material foram realizadas nas amostras obtidas de cada corte/pastejo de cada tratamento, totalizando 72 amostras. Os teores de MS foram obtidos após pré-secagem a $55^{\circ} \mathrm{C}$ e posterior secagem a $105^{\circ} \mathrm{C}$; os de PB, pelo método de Kjeldhal; e os de cinzas, EE e matéria orgânica (MO), seguindo os procedimentos padrão da AOAC, citados por Silva \& Queiroz (2002). As concentrações de FDN, FDA, nitrogênio insolúvel em detergente ácido (NIDA), nitrogênio insolúvel em detergente neutro (NIDN) e lignina em ácido sulfúrico a $72 \%$ foram determinadas de acordo com metodologia descrita por Van Soest et al. (1991).

Os carboidratos totais (CT) foram calculados pela fórmula $\mathrm{CT}=100-(\mathrm{PB}+\mathrm{EE}+$ cinzas $)$ e os não-fibrosos $(\mathrm{CNF})$, que constituem as frações A e B1, foram obtidos pela fórmula $\mathrm{CNF}=\mathrm{CT}-\mathrm{FDNcp}$, em que FDNcp é fibra em detergente neutro isenta de cinzas e proteínas (Sniffen et al., 1992). A fração C foi obtida segundo método proposto por Sniffen et al. (1992), multiplicando-se o valor de lignina por 2,4, e a fração B2, pela diferença entre FDNcp e a fração $C$.

A proteína foi fracionada nas frações $\mathrm{A}+\mathrm{B} 1+\mathrm{B} 2 ; \mathrm{B} 3 \mathrm{e}$ fração $\mathrm{C}$, de modo que a fração $\mathrm{A}+\mathrm{B} 1+\mathrm{B} 2$ foi obtida pela diferença das demais frações com o teor de PB na MS. A fração B3 foi obtida pela diferença entre a proteína insolúvel em detergente neutro (PIDN) e a proteína insolúvel em detergente ácido (PIDA) (Sniffen et al., 1992). A fração C foi determinada pela PIDA (Van Soest et al., 1991). Os valores de PIDA e de PIDN foram calculados multiplicando-se os valores de NIDA e NIDN por 6,25 .

Os tratamentos foram definidos como: AAbC, AMC, AJC, AAbP, AMP, AJP e TAbC, TMC, TJC, TAbP, TMP, TJP, em que: $\mathrm{A}=$ aveia-preta; $\mathrm{e} \mathrm{T}=$ triticale; $\mathrm{Ab}=$ época de plantio abril $; \mathrm{M}=$ maio; $\mathrm{e}=$ junho $; \mathrm{C}=$ corte $; \mathrm{e}=$ = pastejo. As parcelas receberam, concomitantemente, irrigação por 1 hora em intervalos de um dia.

O modelo estatístico foi expresso como:

$$
\begin{aligned}
& \mathrm{Y}=\mathrm{M}+\mathrm{Sis}_{\mathrm{p}}+\mathrm{Sp}_{\mathrm{i}}+\mathrm{Epc}_{\mathrm{j}}+\mathrm{Sis}_{\mathrm{p}} \times \mathrm{Sp}_{\mathrm{i}}+\mathrm{Sis}_{\mathrm{p}} \times \mathrm{Epc}_{\mathrm{i}}+\mathrm{Sp}_{\mathrm{i}} \\
& \times \mathrm{Epc}_{\mathrm{j}}+\mathrm{Sis}_{\mathrm{p}} \times \mathrm{Sp}_{\mathrm{i}} \times \mathrm{Epc}_{\mathrm{j}}+\mathrm{B}_{\mathrm{k}}+\mathrm{e}_{\mathrm{pijk}},
\end{aligned}
$$

em que $\mathrm{M}=$ média geral; Sis $_{\mathrm{p}}=$ sistema de produção, corte ou pastejo; $\mathrm{Sp}_{\mathrm{i}}=$ espécie cultivada; $\mathrm{Epc}_{\mathrm{j}}=$ uma das três épocas de plantio; $\mathrm{Sis}_{\mathrm{p}} \times \mathrm{Sp}_{\mathrm{i}}=$ interação sistema $\times$ espécie; $\mathrm{Sis}_{\mathrm{p}} \times \mathrm{Epc}_{\mathrm{j}}=$ interação sistema $\times$ época de plantio; $\mathrm{Sp}_{\mathrm{i}} \times \mathrm{Epc}_{\mathrm{j}}=$ interação espécie forrageira $\times$ época de plantio; $\mathrm{Sis}_{\mathrm{p}} \times \mathrm{Sp}_{\mathrm{i}}$ $\times \mathrm{Epc}_{\mathrm{j}}=$ interação tripla dos fatores; $\mathrm{B}_{\mathrm{k}}=$ efeito do bloco; e $\mathrm{e}_{\mathrm{ijk}}=$ erro experimental. Os dados obtidos foram submetidos à análise de variância por meio do sistema de análises estatísticas SAS (1996) e as médias comparadas pelo teste Tukey.

\section{Resultados e Discussão}

A análise de variância comprovou efeito significativo $(\mathrm{P}<0,05)$ dos fatores sobre os componentes qualitativos da forragem. Os teores de MS diferiram $(\mathrm{P}<0,05)$ entre as espécies e os sistemas de colheita, com interação sistema de corte $\times$ época de plantio; a média foi de $18,86 \%$ MS e o triticale apresentou maior teor de MS em relação à aveiapreta (Tabela 1).

Os teores de $\mathrm{PB}$ não diferiram $(\mathrm{P}>0,05)$ entre as espécies; obteve-se boa média para o triticale $(21,36 \mathrm{~PB})$ na época junho. Os teores de PB variaram de acordo com a época de plantio (Tabela 2) e indicam que o estádio fisiológico da planta é fator determinante do nível de PB encontrado nas espécies estudadas.

O teor médio de PB foi relativamente elevado em comparação aos descritos na literatura consultada. Soares \& Restle (1999), em consórcio de triticale e azevém, encontraram valores de 19,83 a 25,06\% utilizando níveis crescentes de nitrogênio na adubação. Alvim et al. (1987) trabalharam com aveia-branca e observaram teores de PB de 18,3\% (0\% de N) a 23,4\% (400 kg N/ha) e verificaram também decréscimo no teor de PB com o avanço dos cortes nos tratamentos com níveis de adubação com nitrogênio mais baixos $(0,100$ e $200 \mathrm{~kg} \mathrm{~N} / \mathrm{ha}$ ).

Cecato et al. (2001) avaliaram genótipos de aveia (Avena spp.) e observaram 13,3 a 18,3\% PB na MS. Gomes \& Stumpf (2001), estudando o mesmo cultivar utilizado neste trabalho, obtiveram em diferentes intervalos de corte teores inversamente proporcionais aos intervalos: de 20,5; 18,8 e $18 \%$ de PB na MS nos intervalos 21, 35 e 49 dias, respectivamente.

Houve efeito significativo $(\mathrm{P}<0,05)$ dos fatores e/ou de suas interações sobre os teores dos componentes da parede celular (FDN, FDNcp) e de lignina em detergente ácido

Tabela 1 - Teores médios de matéria seca (MS) de aveia-preta e triticale sob diferentes épocas de plantio e sistemas de corte

\begin{tabular}{llll}
\hline Tratamento & Corte & Pastejo & CV \\
\hline \multicolumn{4}{c}{ Aveia-preta } \\
\hline AAb & $18,93 \mathrm{a}$ & $20,79 \mathrm{a}$ & \\
$\mathrm{AM}$ & $15,62 \mathrm{a}$ & $19,70 \mathrm{a}$ & \\
$\mathrm{AJ}$ & $12,71 \mathrm{a}$ & $18,93 \mathrm{a}$ & 21,39 \\
Média & $15,75 \mathrm{D}$ & $19,81 \mathrm{~B}$ & \\
\hline \multicolumn{5}{c}{ Triticale } \\
\hline TAb & $22,17 \mathrm{a}$ & $29,05 \mathrm{a}$ & \\
T M & $17,70 \mathrm{a}$ & $21,68 \mathrm{ab}$ & \\
TJ & $16,75 \mathrm{a}$ & $19,61 \mathrm{~b}$ & 21,39 \\
Média & $18,87 \mathrm{C}$ & $23,45 \mathrm{~A}$ & \\
\hline
\end{tabular}

Médias na linha/coluna seguidas de mesma letra maiúscula/minúscula não diferem $(P>0,05)$ pelo teste Tukey. 
Tabela 2 - Teores médios de proteína bruta (PB) em aveia-preta e triticale sob diferentes épocas de plantio e sistemas de corte

\begin{tabular}{lllll}
\hline & \multicolumn{4}{c}{ Épocas de plantio } \\
\cline { 2 - 3 } Sistema & Abril & \multicolumn{4}{c}{ Maio } & Junho & CV \\
\hline \multicolumn{5}{c}{ Aveia-preta } \\
\hline Corte & 16,12 & 22,38 & 21,94 \\
Pastejo & 17,63 & 22,38 & 22,96 \\
Média & $16,87 \mathrm{~b}$ & $22,38 \mathrm{a}$ & $22,45 \mathrm{a}$ & $22,45 \mathrm{a}$ \\
\hline \multicolumn{5}{c}{ Triticale } \\
\hline Corte & 17,60 & 19,11 & 20,2 \\
Pastejo & 21,29 & 20,32 & 22,45 \\
Média & $19,39 \mathrm{a}$ & $19,71 \mathrm{a}$ & $21,36 \mathrm{a}$ & 23,29 \\
\hline
\end{tabular}

Médias na linha seguidas pela mesma letra não diferem $(P>0,05)$ pelo teste Tukey.

(Tabelas 3 e 4). O teor de FDN (\%FDN na MS) foi maior no triticale semeado na época abril, possivelmente em decorrência do mesmo fator que promoveu o aumento da porcentagem de inflorescência e de caule + bainha nesta espécie, isto é, o adiantado estádio vegetativo no primeiro corte. Entretanto,os valores médios de FDN não diferiram nonível de 5\% de significância pelo teste Tukey, exceto para aveiapreta do sistema corte: 64,$28 ; 58,09$ e $52,10 \%$ para as épocas abril, maio e junho, respectivamente (Tabela 3). Esses valores de FDN foram superiores à média de 44,6\% de FDN na MS obtida por Gomes \& Stumpf (2001), com o mesmo cultivar de aveia-preta utilizado neste trabalho, sob doses de nitrogênio e três diferentes intervalos de corte (49, 35 e 21 dias) e com o primeiro corte aos 50 dias pós-plantio. $\mathrm{O}$ fato de as plantas semeadas em abril apresentarem inflorescência, neste trabalho, culminando em maiores valores de \%FDN na MS, corrobora os resultados descritos por Primavesi et al. (2001), que analisaram três cultivares de aveia e observaram que o cv. IAPAR 61 apresentou menores teores de FDN na MS nos intervalos de corte de 28 e 35 dias (48,9 e 50,6\% para o plantio de abril e 49,4 e 51,8\% para o plantio de maio).

Cecato et al. (2001), estudando níveis de $\mathrm{N}$ em aveiapreta cv. IAPAR 61, não observaram variação na \%FDN na MS entre os níveis de 0,50, 100 e $200 \mathrm{~kg}$ N/ha (40,8 e 49.2\% de FDN na MS para o 10 e 20 cortes, respectivamente). Os valores de FDN superiores no segundo corte foram atribuídos ao amadurecimento das plantas com o aumento do conteúdo de parede celular, o que, neste trabalho, pode explicar os maiores valores obtidos tanto com a aveia-preta quanto com o triticale.

A mesma tendência pôde ser notada quanto aos teores de FDN isenta de cinzas e proteína (FDNcp) e de lignina (Tabela 4), o que fortalece esta afirmativa de que ocorrem aumento dos constituintes da parede celular e progressiva lignificação deste material. Os teores de FDNcp na MS, da mesma forma que os de FDN, variaram com a espécie e a época de plantio e foram influenciados pela interação espécie $\times$ época de plantio.

As diferenças entre os teores médios de lignina na MS de aveia-preta e triticale (Tabela 4) obtidas pelo teste Tukey não indicam distinção entre os sistemas e as épocas de plantio. Uma análise mais detalhada da composição das frações das forrageiras poderia indicar a natureza da distinção entre os conteúdos de lignina das espécies estudadas; o triticale apresentou maior teor $(\mathrm{P}<0,05)$, em virtude da maior proporção de caules e inflorescências possivelmente mais lignificadas.

Não houve efeito $(\mathrm{P}>0,05)$ dos fatores estudados sobre os teores de FDA, nitrogênio insolúvel em detergente neutro (\%NIDN) e nitrogênio insolúvel em detergente ácido (\%NIDA). O teor de extrato etéreo determinado nas amostras de cada tratamento não diferiu estatisticamente $(\mathrm{P}>0,05)$ entre as espécies, as épocas de plantio e os sistemas de colheita e apresentou média de $1,70 \%$ da MS.

O teor de cinzas diferiu $(\mathrm{P}<0,05)$ entre as espécies e os sistemas, com valor médio de $9,14 \%$ da MS. O maior valor foi obtido com aveia-preta no sistema corte e o menor, com triticale no sistema pastejo (Tabela 5). Essas distinções podem estar relacionadas à natureza de captação de nutrientes, seja pelo melhor enraizamento em volume de solo explorado seja pela maior capacidade da aveia-preta em explorar nutrientes minerais nas condições deste trabalho. A forma como foi localizado o adubo fosfatado no sistema corte, quando plantado em linha, pode ter causado melhor aproveitamento desse nutriente, tão importante para o estabelecimento das raízes, o que, da mesma forma, favoreceria a captação desses nutrientes e o enriquecimento da forragem em minerais, expressos como cinzas na MS.

$\mathrm{O}$ teor de $\mathrm{CT}$ em relação à MS variou com a época de plantio $(\mathrm{P}<0,05)$, com média de $77,83 \%$ da MS, e não diferiu significativamente entre as espécies e os sistemas. $\mathrm{Na}$ comparação dos teores de CT em porcentagem (\%CT na MS) nas duas espécies sob os sistemas corte e pastejo (Tabela 6), observou-se tendência a maiores valores na época abril para as duas espécies nos dois sistemas.

Houve efeito dos sistemas e das épocas de plantio $(\mathrm{P}<0,05)$ sobre os conteúdos de $\mathrm{CNF}$ em ambas as espécies e interação espécie $\times$ época de plantio, no entanto, não se confirmou o efeito significativo pelo teste Tukey entre as três épocas de plantio (Tabela 3). O efeito do sistema sobre o conteúdo de CNF pode ser atribuído à competição intraespecífica no sistema corte, causada pelo maior adensamento, que possivelmente reduziu a espessura dos colmos e diminuiu a participação dos carboidratos fibrosos na forragem colhida neste sistema. 
Houve interação das espécies dentro das épocas de plantio $(\mathrm{P}<0,05)$. Essa interação influenciou os teores de CNF na base da MS (\% CNF na MS), indicando diferenças entre as espécies dentro das épocas de plantio abril, maio e junho (Tabela 7).

Tabela 3 - Teores de fibra em detergente neutro (FDN), fibra em detergente neutro isenta de cinzas e proteína (FDNcp) e carboidratos não-fibrosos (CNF) na matéria seca de aveia-preta e triticale cultivados em três épocas de plantio

\begin{tabular}{lcccc}
\hline & \multicolumn{3}{c}{ Época de plantio } \\
\cline { 2 - 3 } Espécie & Abril & Maio & Junho & Média \\
\hline & \multicolumn{4}{c}{ FDN $(\% \text { MS })^{1}$} \\
Corte & & & \\
Aveia-preta & $64,28 \mathrm{a}$ & $58,09 \mathrm{ab}$ & $52,10 \mathrm{~b}$ & $57,82 \mathrm{D}$ \\
Triticale & $66,33 \mathrm{a}$ & $62,60 \mathrm{a}$ & $59,53 \mathrm{a}$ & $62,82 \mathrm{~B}$ \\
Pastejo & & & & \\
Aveia-preta & $59,51 \mathrm{a}$ & $66,14 \mathrm{a}$ & $54,76 \mathrm{a}$ & $60,14 \mathrm{C}$ \\
Triticale & $65,89 \mathrm{a}$ & $61,81 \mathrm{a}$ & $67,24 \mathrm{a}$ & $64,98 \mathrm{~A}$ \\
\hline
\end{tabular}

FDNcp $(\% \mathrm{MS})^{1}$

Corte

$\begin{array}{cccc}\text { Aveia-preta } & 62,23 \mathrm{Ba} & 57,07 \mathrm{Aa} & 50,92 \mathrm{Aa} \\ \text { Triticale } & 64,37 \mathrm{Aa} & 54,09 \mathrm{Bab} & 50,95 \mathrm{Ab} \\ \begin{array}{c}\text { Pastejo } \\ \text { Aveia-preta }\end{array} & 58,23 \mathrm{Ba} & & \\ \text { Triticale } & 64,90 \mathrm{Aa} & 64,52 \mathrm{Aa} & 54,23 \mathrm{Ba} \\ \end{array}$

$\mathrm{CNF}(\% \mathrm{MS})^{2}$

Corte

\begin{tabular}{ccccc} 
Aveia-preta & $19,14 \mathrm{a}$ & $18,53 \mathrm{a}$ & $25,84 \mathrm{a}$ & $21,17 \mathrm{~A}$ \\
Triticale & $16,69 \mathrm{a}$ & $25,19 \mathrm{a}$ & $26,58 \mathrm{a}$ & $22,82 \mathrm{~A}$ \\
Pastejo & & & & \\
Aveia-preta & $22,38 \mathrm{a}$ & $11,07 \mathrm{a}$ & $19,92 \mathrm{a}$ & $17,79 \mathrm{~B}$ \\
Triticale & $11,63 \mathrm{a}$ & $23,59 \mathrm{a}$ & $18,75 \mathrm{a}$ & $17,99 \mathrm{~B}$ \\
\hline
\end{tabular}

${ }^{1}$ Médias na coluna/linha seguidas pela mesma letra maiúscula/minúscula não diferem $(P>0,05)$ pelo teste Tukey.

2 Médias seguidas de letras maiúsculas/minúsculas diferentes na coluna/ linha diferem $(P<0,05)$ pelo teste Tukey.

Tabela 4 - Teores médios de lignina e fração $C$ dos carboidratos de aveia-preta e triticale cultivados em três épocas de plantio

\begin{tabular}{|c|c|c|c|c|}
\hline \multirow[b]{2}{*}{ Espécie } & \multicolumn{3}{|c|}{ Época de plantio } & \multirow[b]{2}{*}{ Média } \\
\hline & Abril & Maio & Junho & \\
\hline & \multicolumn{4}{|c|}{ Lignina $(\% \mathrm{MS})^{1}$} \\
\hline Aveia-preta & $3,56 \mathrm{a}$ & $3,16 \mathrm{a}$ & $2,47 \mathrm{a}$ & $3,06 \mathrm{~B}$ \\
\hline \multirow[t]{2}{*}{ Triticale } & $4,44 \mathrm{a}$ & $3,49 a$ & $3,75 \mathrm{a}$ & $3,89 \mathrm{~A}$ \\
\hline & \multicolumn{4}{|c|}{ Fração C $(\% \mathrm{MS})^{2}$} \\
\hline Aveia-preta & $8,55 \mathrm{a}$ & $7,58 \mathrm{~b}$ & $6,34 \mathrm{c}$ & $7,49 \mathrm{~B}$ \\
\hline Triticale & $10,65 \mathrm{a}$ & $8,37 \mathrm{c}$ & $9,01 \mathrm{~b}$ & $9,34 \mathrm{~A}$ \\
\hline
\end{tabular}

${ }^{1}$ Médias na coluna/linha seguidas pela mesma letra maiúscula/minúscula não diferem $(P>0,05)$ pelo teste Tukey.

${ }^{2}$ Médias seguidas por letras maiúsculas/minúsculas diferentes na mesma coluna/linha diferem significativamente pelo teste $F(P<0,05)$.
Tabela 5 - Teores médios de cinzas na matéria seca na aveiapreta e no triticale em dois sistemas de corte

\begin{tabular}{lccc}
\hline Espécie & Corte & Pastejo & Média \\
\hline Aveia-preta & $10,45 \mathrm{a}$ & $9,46 \mathrm{~b}$ & $9,95 \mathrm{~A}$ \\
Triticale & $9,05 \mathrm{a}$ & $7,07 \mathrm{~b}$ & $8,06 \mathrm{~B}$ \\
\hline
\end{tabular}

Médias na coluna/linha seguidas pela mesma letra maiúscula/minúscula não diferem $(P>0,05)$ pelo teste Tukey.

Tabela 6 - Teores médios de carboidratos totais e fração solúvel em detergente neutro de aveia-preta e triticale cultivados em três épocas de plantio

\begin{tabular}{llll}
\hline & \multicolumn{3}{c}{ Época de plantio } \\
\cline { 2 - 4 } Espécie & Abril & Maio & Junho \\
\hline
\end{tabular}

Carboidratos totais $(\% \mathrm{MS})^{1}$

Corte

\begin{tabular}{|c|c|c|c|}
\hline Aveia-preta & $81,37 \mathrm{a}$ & $75,60 \mathrm{c}$ & $76,32 b$ \\
\hline Triticale & $81,06 a$ & $79,23 b$ & $77,53 \mathrm{c}$ \\
\hline \multicolumn{4}{|l|}{ astejo } \\
\hline Aveia-preta & $80,77 \mathrm{a}$ & $75,59 b$ & $75,00 \mathrm{c}$ \\
\hline Triticale & $76,53 b$ & $78,25 \mathrm{a}$ & $75,15 c$ \\
\hline
\end{tabular}

Corte

\begin{tabular}{lccc} 
Aveia-preta & $15,34 \mathrm{~b}$ & $21,31 \mathrm{a}$ & $21,22 \mathrm{a}$ \\
Triticale & $16,58 \mathrm{c}$ & $17,54 \mathrm{~b}$ & $19,42 \mathrm{a}$ \\
& & & \\
Pastejo & & & \\
& & & \\
Aveia-preta & $16,65 \mathrm{c}$ & $21,30 \mathrm{~b}$ & $21,85 \mathrm{a}$ \\
Triticale & $20,18 \mathrm{~b}$ & $19,16 \mathrm{c}$ & $21,55 \mathrm{a}$ \\
\hline
\end{tabular}

A aveia-preta na época de plantio maio produziu menor teor de CNF, provavelmente porque é composta de um material em estádio fisiológico menos avançado e em virtude da possível presença de grãos no triticale.

$\mathrm{Na}$ fração B2, houve diferença estatística $(\mathrm{P}<0,05)$ entre as épocas de plantio e interação espécie $\times$ época de plantio (Tabela 7). Houve diferença pelo teste Tukey $(\mathrm{P}<0,05)$ dentro do tratamento triticale no sistema corte e entre as épocas de plantio: abril $(53,97 \%)$, maio $(45,97 \%)$ e junho $(44,66 \%)$, o que pode ser atribuído ao avanço fisiológico no primeiro corte na época abril, o que aumentaria a fração B2 (celulose e hemicelulose), de maneira oposta à época junho, que se apresentava em fase inicial de perfilhamento. Essas características, principalmente no triticale, indicam uma forragem "imatura" quanto aos conteúdos fibrosos.

Foram observadas diferenças significativas $(\mathrm{P}<0,05)$ entre as porcentagens médias da fração $\mathrm{C}$ dos carboidratos nas duas espécies e entre as épocas de plantio, o que 
confirma a maior lignificação da fibra no triticale semeado em abril (Tabela 4). Essas diferenças poderiam ser elucidadas pela análise dos carboidratos de cada componente da massa de forragem, pois a presença de grande porção de inflorescência na espécie triticale, um órgão composto de grãos cobertos por espessa proteção pela pálea e pelo lema, indica que essa espécie é rica em lignina e celulose indisponível.

Os teores de CNF da aveia-preta $(25,5 \%$ nos CT) e do triticale $(19,20 \%$ nos CT) neste trabalho foram maiores que os obtidos por Lista et al. (2007), em capim-mombaça e capim-elefante, duas espécies de clima tropical $(14,09$ e $7,74 \%$ nos CT, respectivamente).

No entanto, os teores da fração B2 de aveia-preta e triticale (Figuras 1 e 2 ) neste trabalho foram menores que os descrito por esse autor (72,2 e 75,8\% para capim-elefante e o capim-mombaça), o que demonstra menor participação dos componentes fibrosos no carboidrato total das espécies de inverno em relação às de clima tropical.

Tabela 7 - Teores médio de carboidratos não-fibrosos e fração B2 de aveia-preta e triticale cultivados em três épocas de plantio

\begin{tabular}{llcc}
\hline & \multicolumn{3}{c}{ Época de plantio } \\
\cline { 2 - 4 } Espécie & Abril & Maio & Junho \\
\hline & \multicolumn{3}{c}{ Carboidratos não-fibrosos $(\% \mathrm{MS})^{1}$} \\
Aveia-preta & $22,66 \mathrm{~A}$ & $14,80 \mathrm{~B}$ & $23,30 \mathrm{~A}$ \\
Triticale & $14,1 \mathrm{~B}$ & $24,39 \mathrm{~A}$ & $22,66 \mathrm{~B}$ \\
\hline
\end{tabular}

Fração B2 $(\% \mathrm{MS})^{2}$

\begin{tabular}{llll} 
Aveia-preta & $51,76 \mathrm{Bb}$ & $53,21 \mathrm{Aa}$ & $48,48 \mathrm{Ac}$ \\
Triticale & $53,97 \mathrm{Aa}$ & $45,97 \mathrm{Bb}$ & $44,66 \mathrm{Bc}$ \\
\hline
\end{tabular}

${ }^{1}$ Médias seguidas de letras diferentes na coluna diferem $(\mathrm{P}<0,05)$ pelo teste F.

2 Médias seguidas de letras maiúsculas/minúsculas diferentes na mesma linha/coluna diferem $(P<0,05)$ pelo teste $F$.

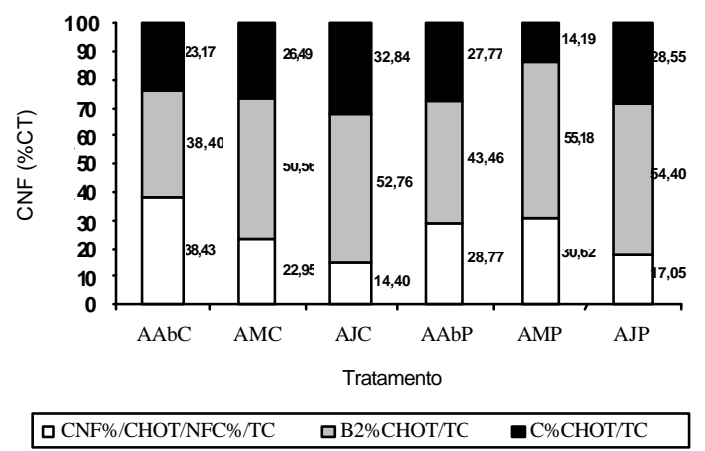

Figura 1 - Teores médios de carboidratos não-fibrosos (CNF), fração $B 2 \%$ e fração $C \%$ em relação ao conteúdo de carboidratos totais na aveia-preta semeada em abril, maio e junho e colhida nos sistemas corte ou pastejo.
As frações $\mathrm{C}$ dos carboidratos nas gramíneas estudadas apresentaram valores superiores aos relatados por Lista et al. (2007) (9,6 e 13,9 para os capins elefante e mombaça, respectivamente), o que pode ser atribuído ao fato de que o material coletado por este autor consistiu de uma simulação de pastejo na qual predominaram folhas obtidas em amostras de plantas em estádio vegetativo, indicativo de menor lignificação da fibra em relação ao material obtido neste trabalho, ou ao fato de este material, mais rico em açúcares, ter se tornado indisponível pela reação de Maillard mesmo quando se trabalhou com baixa temperatura de présecagem $\left(55^{\circ} \mathrm{C}\right)$.

As frações mais solúveis dos carboidratos que compõem a aveia-preta e o triticale atendem ao propósito de alimento suplementar em sistemas à base de forrageiras tropicais, uma vez que estas forrageiras apresentam altos teores destas frações no momento em que há maior demanda por volumosos com fibra de melhor qualidade, em razão da redução da qualidade das forrageiras na entressafra e da redução da degradabilidade da fibra e dos teores das frações A e B1 em relação aos CT (Van Soest et al., 1991). As variações nos teores de $\mathrm{CNF}$, da fração $\mathrm{B} 2$ e da fração $\mathrm{C}$, expressas em relação ao CT, entre as épocas de plantio indicam que a aveia-preta, no plantio de junho, por atravessar um período de temperaturas médias mais baixas (menor soma térmica ao primeiro corte/pastejo), ainda não teria acumulado todo o seu potencial de produção de carboidratos de maior solubilidade, como as frações A + B1 e B2; o triticale na época abril, no entanto, proporcionou maiores frações, possivelmente em virtude da presença de grãos em início de formação, o que explica o maior teor de CNF, que, de certo modo, compensaria o maior teor de lignina na MS decorrente da lignificação sofrida pela fração C tanto do carboidrato quanto da proteína.

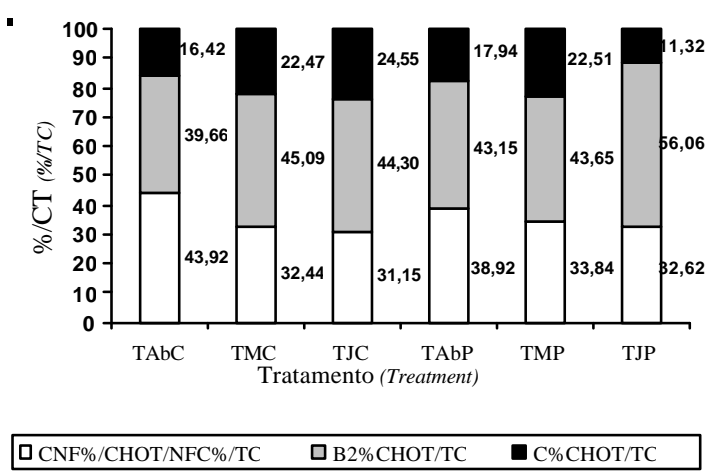

Figura 2 - Teores médios de carboidratos não-fibrosos (CNF), fração $\mathrm{B} 2 \%$ e fração $\mathrm{C} \%$ em relação ao conteúdo de carboidratos totais no triticale semeado em abril, maio e junho e colhido nos sistemas corte ou pastejo. 
O fracionamento dos compostos nitrogenados das espécies estudadas revelou alta proporção de frações solúveis na PB, além de elevados teores desse nutriente, e indica que essas espécies constituem excelente fonte suplementar de proteínas, apesar de terem produzido grande proporção de inflorescência, em decorrência da antecipação de seus ciclos fenológicos.

Não houve efeito significativo $(\mathrm{P}>0,05)$ dos fatores sobre os teores de proteína solúvel em detergente neutro (\%PSDN na MS), da fração B3 (\% B3 na MS) e da fração C. Houve apenas diferenças $(\mathrm{P}<0,05)$ entre as médias das épocas de plantio na fração solúvel da proteína, que corresponde aos compostos nitrogenados não-protéicos, aos peptídeos e aminoácidos, assim como às proteínas de maior solubilidade. Essas diferenças são atribuídas aos diferentes teores de PB obtidos nas forrageiras em cada tratamento.

Os valores médios da FDN na MS nos diferentes tratamentos diferiram entre as épocas de plantio nas duas espécies e nos dois sistemas de corte (Tabela 6); os menores valores foram obtidos pela aveia-preta na época de plantio abril, comprovando que se trata de um material mais tenro e rico em proteína bruta, devido ao estádio fisiológico ao primeiro corte.

Estes dados esclarecem a natureza destas forrageiras quanto ao fracionamento da proteína e à predominância das frações solúveis. A participação de cada fração protéica em relação à $\mathrm{PB}$ foi similar entre a aveia-preta e o triticale (Figuras 3a e 3b) e denota alta qualidade da proteína produzida nestas espécies. A espécie, o sistema e a época de plantio não tiveram efeito sobre os componentes de menor degradação da proteína, o que comprova a equiva- lência das frações B3 e C entre os tratamentos com a elevação da participação das frações mais solúveis no plantio de junho, independentemente da espécie e do sistema de colheita.

Vale ressaltar as diferenças entre a solubilidade da proteína dessas forrageiras em relação ao observado por Lista et al.(2007), em simulação de pastejo com gramíneas de clima tropical. Esses autores observaramque as frações de menor solubilidade (fração B3) e insolúveis (fração C) equivaleram a 10,9 e 10,4\% da PB e 19,9 e 7,6\% da PB para os capins elefante e mombaça, respectivamente. Neste estudo, os valores da fração B3 variaram de 3 3,03 a 5\% da PB e 3,85 a 6,06\% da $\mathrm{PB}$ para aveia-preta e triticale, respectivamente, e os valores da fração $C$ variaram de 0,27 a $0,57 \%$ da $P B$ para aveia-preta e 0,26 a $0,94 \%$ da PB para o triticale (Figuras 3 e 4).

Malafaia et al. (1996) observaram valores médios das frações B3 e C de alguns alimentos superiores aos encontrados neste estudo para aveia-preta e triticale; no farelo de soja, encontraram 2,18 e 1,38\% da PB e na silagem de milho, 14,77 e $12,25 \%$ da PB para as frações B3 e C, respectivamente.

A solubilidade da proteína não é fator limitante nestas forragens. Portanto, é importante produzir forragem com alto teor de $\mathrm{PB}$, o que pode ser alcançado com alta porcentagem de folhas, alta relação lâmina foliar/caule + bainha em plantas cultivadas em solo com boas condições de fertilidade e umidade.

Uma vez que a forragem produzida por estas espécies é rica em CNF e PSDN, quanto maior sua participação na fração volumosa da dieta de ruminantes durante a entressafra das pastagens tropicais, melhor o padrão de fermentação do rúmen para manter o equilíbrio entre os ácidos graxos

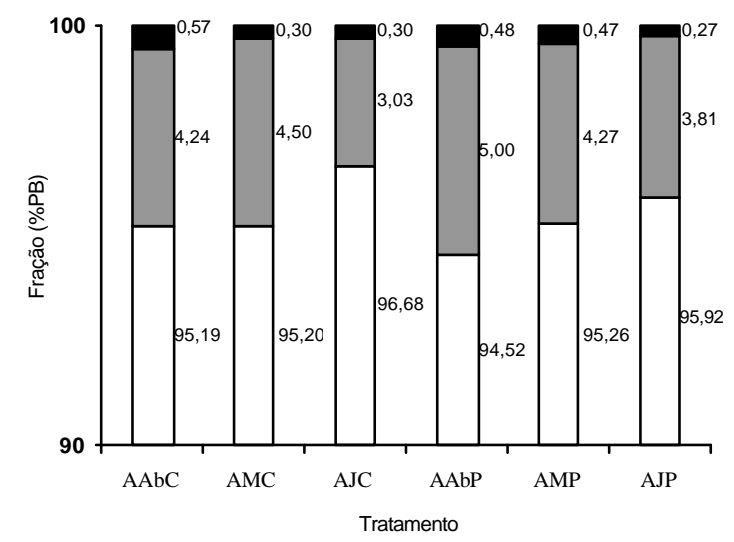

$\square$ Prot sol\%PB / Sol Prot\%CP $\square \mathrm{B} 3 \% \mathrm{~PB} / \mathrm{CP} \quad \mathrm{C} \% \mathrm{~PB} / \mathrm{CP}$

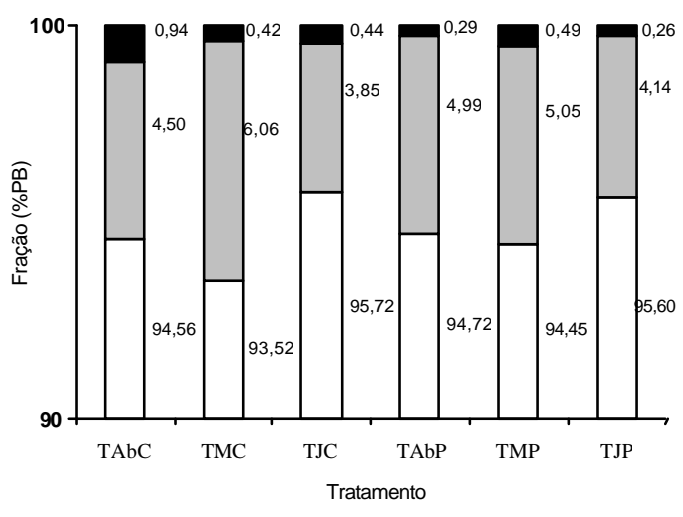

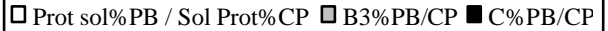

Figura 3 - Teores médios de proteínas solúveis, fração B3 e fração $C$ em relação ao conteúdo de PB da aveia-preta semeada em abril, maio e junho (médias de todas as avaliações) e colhida nos sistemas corte ou pastejo (A) e teores médios de proteínas solúveis, fração B3 e fração $C$ em relação ao conteúdo de PB de triticale semeado em abril, maio e junho (médias de todas as avaliações) e colhido nos sistemas corte ou pastejo (B). 
voláteis (acético: propiônico: butírico) e reduzir as perdas de nitrogênio via uréia na urina.

$\mathrm{O}$ ambiente de cultivo destas forrageiras tem grande influência sobre a duração do ciclo fenológico, que pode ter variado de acordo com o ano de plantio, e até mesmo com o local de plantio, na região onde foi realizado o experimento.

\section{Conclusões}

As espécies aveia-preta e triticale produzem forragem de boa qualidade na região norte do Rio de Janeiro. A alta concentração de proteína e os baixos teores de constituintes da parede celular, especialmente FDNcp, permitem a produção de considerável quantidade de proteína e energia por hectare na forma de forragem suplementar. O estádio fisiológico das plantas no momento das avaliações indicou redução dos teores de proteína bruta e acréscimo dos constituintes da parede celular na época de plantio abril em relação ao plantio em junho. A alta solubilidade dos carboidratos e das proteínas tanto da aveia-preta quanto do triticale indica a qualidade destas forrageiras e a possibilidade de sua utilização como importante suplemento forrageiro nos sistemas à base de pastagens tropicais. $\mathrm{O}$ uso destas forrageiras no período seco do ano pode suprir a deficiência de fibra disponível e proteína e promover a manutenção do padrão de fermentação do rúmen, melhorando o desempenho dos ruminantes neste período.

\section{Literatura Citada}

ALVIM, J.M.; MARTINS, C.E.; COSER, A.C. et al. Efeito da fertilização nitrogenada na produção de MS e PB da aveia (Avena sativa) na zona da mata de Minas Gerais. Revista da Sociedade Brasileira de Zootecnia, v.16, n.4, p.394-401, 1987.

ALVIM, J.M. Produção e utilização de forrageiras de inverno: aveia e azevém. Coronel Pacheco: EMBRAPA-CNPGL, 1989. 28p. (Documentos, 42).

CARDoso, R.M.; PACHECO, E.; CARVALHO, J.G. et al. Competição entre variedades forrageiras de inverno. In: REUNIÃO ANUAL DA SOCIEDADE BRASILEIRA DE ZOOTECniA, 9., 1972, Viçosa, MG. Anais... Viçosa, MG: Sociedade Brasileira de Zootecnia, 1972. p.279-288.

CECATO, U.; RÊGO, F.C.A.; GOMES, J.A.N. et al. Produção e composição química em cultivares e linhagens de aveia (Avena spp.). Acta Scientiarum, v.23, n.4, p.775-780, 2001.

EMBRAPA CNPT [2000]. VII Reunião Brasileira de Pesquisa de triticale. Disponível em: <http://www.embrapa.cnpt.org.br Disponível em: 29/7/2003.

FARIA, V.P.; CORSI, M. Forragens de inverno. PEIXOTO, A.M.; MOURA, J.C.; FARIA, V.P. (Ed.) Volumosos para bovinos. 1.ed. Piracicaba: Fundação de Estudos Agrários Luiz de Queiroz, 1995. p.227-231.

FELICIO, J.C.; CAMARGO, C.E.O.; FERREIRA FILHO, A.W.P. et al. Avaliação de genótipos de triticale e trigo em ambientes favoráveis e desfavoráveis no Estado de São Paulo. IAC Bragantia, v.60, n.2, p.83-91, 2001.

GALLO, C.H. Avaliação da aveia preta (Avena strigosa screb) e de cultivares de aveia amarela (Avena bizanthina Koch) sob diferentes sistemas de manejo. Jaboticabal: Universidade Estadual Paulista, 1991. 42p. Monografia (Graduação em Zootecnia) - Universidade Estadual Paulista, 1991.

GOMES, J.F.; STUMPF JR., W. Intervalos de corte e adubação nitrogenada em Aveia preta EMBRAPA 29 (GAROA). In: REUNIÃO ANUAL DA SOCIEDADE BRASILEIRA DE ZOOTECNIA, 38., 2001, Piracicaba. Anais... Piracicaba: Sociedade Brasileira de Zootecnia, 2001. (CD-ROM).

PEDRO JR., M.J.; CAMARGO, M.B.P. et al. Temperatura-base grau-dia e duração do ciclo para cultivares de triticale. Bragantia, v.63, n.3, p.447-453, 2004

SARAN JR., A.J.; REIS, R.A.; MOREIRA, A.L. et al. Avaliação de cultivares de Aveia sob pastejo em Jaboticabal-SP. Anais... REUNIÃO ANUAL DA SOCIEDADE BRASILEIRA DE ZOOTECNIA, 40., 2003, Santa Maria: Sociedade Brasileira de Zootecnia, 2003. (CD-ROM).

LINN, J.G.; MARTIN, N.P. Forage quality analyses and interpretation. The Veterinary Clinics of North America Food Animal Practice, v.7, n.2, p.509-523, 1991.

LISTA, F.N.; SILVA, J.F.C.; MALDONADO, H.V. et al. Avaliação nutricional de pastagens de capim-elefante e capim-mombaça sob manejo rotacionado em função do período de ocupação. Revista Brasileira de Zootecnia, v.36, n.5, p.1406-1412, 2007.

MALAFAIA, P.A.M.; VALADARES, F.S.C.; COELHO DA SILVA, J.F. et al. [1996]. Determinação das frações que constituem a proteína bruta de alguns volumosos e concentrados. Anais eletrônicos... www.sbz.org.br/eventos/Fortaleza/ Nut_rumilSbz.159.pdf Acesso em: 21/9/2005.

PRIMAVESI, A.C.; PRIMAVESI, O.; CHINELATO, A. et al. Indicadores de determinação de cortes de cultivares de aveia forrageira. Scientia Agrícola, v.58, n.1, p.79-89, 2001.

REIS, R.A; MOREIRA, A.L.; SEIXAS, P.F. et al. Avaliação de gramíneas anuais de inverno para produção de forragem em Jaboticabal - SP. In: REUNIÃO ANUAL DA SOCIEDADE BRASILEIRA DE ZOOTECNIA, 39., 2002, Recife. Anais.. Recife: Sociedade Brasileira de Zootecnia, 2002. (CD-ROM).

ROYO, C.; INSA, J.A.; BOUJENNA, A. et al. Yield and quality of spring triticale for forage and grain as influenced by sowing date and cutting stage. Field Crops Research, v.37, n.3, p.161168,1994

SILVA, D.J.; QUEIROZ, A.C. Análise de alimentos: métodos químicos e biológicos. 3.ed. Viçosa, MG: Universidade Federal de Viçosa, 2002. 235p.

SNIFFEN, C.J.; O'CONNOR, J.D.; van SOEST, P.J. et al. A net carbohydrate and protein system for evaluation cattle diets. II. Carbohydrate and protein availability. Journal of Animal Science, v.70, n.11, p.3562-3577, 1992

SOARES, A.; RESTLE, J. Produção e qualidade de forragem de pastagem de triticale e azevém submetida a doses de adubação nitrogenada. Revista Brasileira de Zootecnia, v.31, n.2, p.908-917, 2002.

STATISTICAL ANALYSES SYSTEM - SAS. SAS/STAT ${ }^{\text {TM: SAS }}$ user's guide for windows environment. Version 6, 4.ed. Cary: 1996. 1686p.

TEIXEIRA, M.C.; ABREU, J.B.R.; MENEZES, J.B.O.X. et al. Efeito de doses de nitrogênio sobre a produção de matéria seca de cultivares de aveia forrageira. In: ZOOTEC, 2002, Rio de Janeiro. Anais... Rio de Janeiro: 2002. (CD-ROM).

Van SOEST, P.J.; ROBERTSON, J.B.; LEWIS, B.A. Methods of the determination of FDN, FDA and CNE. Journal of Dairy Science, v.74, p.3583-3597, 1991. 